Vol. 1, No. 1, 1993

\title{
FLAVONOIDS IN CULTIVARS OF SOYBEAN: ANTIOXIDANT ACTION
}

Tanus Jorge Nagem*, Tânia Toledo de Oliveira e Albuquerque,

Luiz Carlos Guedes de Miranda

Departamento de Química

Universidade Federal de viçosa

Avenida $P$. H. Rolphs, s/n

Vifosa, Minas Gerais, BRASIL 36570-000

$\&$

Marilda Conceição da Silva

Departamento de Quimica

Universidade Federal de Minas Gerais

Pampulha, Cidade Universitaria

Belo Horizonte, Minas Gerais, BRASIL 30161

\begin{abstract}
The purpose of this investigation was the identification, quantification and determination of antioxidant activity of flavonoids of soybean. Examination of nine cultivars was carried out. All of them had the same stage of maturity and were grown on the same soil. The results showed the presence of genistein, genistin, daidzein, daidzin, naringenin, kaempherol, formonometin and biochanin $A$ in all cultivars. In terms of antioxidant activity, the best results were obtained with genistein and genistin.
\end{abstract}

KEYWORDS: Flavonoids, soybean, antioxidant action.

\section{RESUMO}

o propösito do presente estudo foi a identificacão, quantificąão e determinąão da ą̃̃o antioxidante de compostos flavonöidicos em sementes de soja. Foram examinados nove cultivares, todos no mesmo estágio de desenvolvimento e cultivados no mesmo solo. Os resultados experimentais mostraram a presenca de genisteina, genistina, daidzeiona, daidzina, naringenina, kaempherol, formonometina e biochanina $A$ em todos os cultivares. Os melhores resultados de acão antioxidante foram obtidos com genisteina e genistina.

\section{INTRODUCTION}

Flavonoid compounds have been studied for many years, particularly because of their use in a variety of areas including food industry $1-3$, mycology and plant physiology 4 , phytopathology4-6, microbiology 7 , biochemical ecology $7-10$, entomology 8 and chemistry 11 .

We decided to identify and study this type of compounds and consider some of their applications, because of their world wide economic importance. The use of flavonoid compounds

* Author to whom correspondence should be addressed. 
as antioxidant agents ${ }^{1-3}$, antifunga $1^{4-6}$, antibacterial agents ${ }^{7}$, as well as insect repel1ents, sweeteners ${ }^{9}$, estrogenics 10,11 and phytoalexins 4 has been described in the literature. The purpose of this work was to isolate, identify, quantify and above all test these secondary matabolites as antioxidizing agents.

\section{MATERIALS AND METHODS}

Flavonoid compounds were extracted from soybean seeds obtained from nine cultivars at the same stage of maturity and grown on the same soil. The procedure described by Naiml2 was used for genistein (I), genistin (II), daidzein(III) and daidzin (IV). The soybean seeds, ground ( 40 mesh), were extracted exhaustively with hexane and $60 \%$ ethanol. After evaporation of the solvent, the extract was treated with acetone ( 2 to 1$)$ and filtered. After evaporation of the solvent, the soluble portion was adsorbed on silica gel $200 \mathrm{G}$, followed by exhaustive extraction with acetone for three days. The residue obtained after evaporation of the solvent was crystallized from $80 \%$ ethanol and washed with chloroform.

The compounds naringenin (V), kaempherol (VI), formonometin (VII) and biochanin A (VIII) were extracted according to the method described by Murphyl3. The sample was heated in acetic acid for 10 minutes using a water bath. The filtered product, after 1 hour hydrolysis with $1,00 \mathrm{~N} \mathrm{HCl}$ was extracted with anhydrous diethyl ether and the solvent was evaporated.

The flavonoid compounds genistein, genistin, daidzein, daidzin, kaempherol, formonometin, biochanin $A$ were isolated by thin layer chromatography and identified by ultraviolet and infrared spectroscopy, proton nuclear magnetic resonance and melting point. Comparison with standars available in our laboratory was also done.

The quantification was done by HPLC according to the method described hy Eldrige16. A Corasil $\mathrm{C}-18.30 \mathrm{~cm} \times 30 \mathrm{~mm}$ ID column was: employed.Polar eluents such as water-methanol (25-50\%) for 20 min and a flux ratio of $1 \mathrm{ml} / \mathrm{min}$ (with $\mathrm{N}$-butyrophenone as internal standard) were used.

The antioxidant activity of the flavonoid compounds mixed with soybean oil was obtained by determining the acidity, iodine and peroxide indexes using the method described by Pregnolatto14. The determination of the acidity index involved the titration with $0,1 \mathrm{~N} \mathrm{NaOH}$ using phenolphthalein as an indicator. The iodine index was deternined by thiosulfate titration of the excess iodine of the sample, previously dissolved in chloroform and treated with fresh $15 \% \mathrm{KI}$. solution.

The peroxide index was determined by dissolving the sample in acetic acid-chloroform solution ( 3 to 2 ), addition of $1 \%$ starch solution $(0,5 \mathrm{~m} 1)$, titration of the excess iodine with $0,01 \mathrm{~N}$ sodium thiosulfate and comparison to a blank solution under the same conditions.

The quantification of the protein in the soybean seeds was performed using the method of Bradford15 and the determination of iipid content was done according to the procedure described by pregnolatto14. 


\section{RESULTS AND DISCUSSION}

The identification of the flavonoid compounds was done using ultraviolet, infrared and proton nuclear magnetic resonance spectroscopy and comparison to standard samples available in the laboratory. Tables I, II, III and IV sumarize the experimental results obtained by the different tecnhiques. Figure 1 illustrates the chemical structures of the flavonoids studied.

$T a b l e V$ shows the average values obtained for protein, oil and flavonoid compounds extracted from the nine cultivars studied. As can be seen, Cultivar UFV-5' showed the highest contents for all the parameters determined.

It is well known that great part of the phenolic compounds is found in plants bound to proteins 17 . In fact, in Cicer arietanum, member of the Leguminosae, the vast majority of protein is found along with a large quantity and a variety of flavonoid compound 17 .

These results are wholly justifiable, if one considers that flavonoid compounds are involved in nitrogen fixation in plants $23-26$. This process, that begins vith the capture of nitrogen, involves the synthesis of phenylalanine and thyrosine in one of the metabolic pathways. Both amino acids are precursors of flavonoid compounds in plants. Of course, the fixation of nitrogen also leads to the biosynthesis of proteins.

Analysis of the results shown in Table $: \mathrm{V}$ also shows that the average values obtained for daidzin (IV) are higher than those for daidzein (III) and that the values obtained for genistin (II) are higher than those of genistein (I). This is in acoordance with the results described by farmalidis 18 . This may be attributed to the need of glucose/sulfate/glucuronate incorporation in the detoxification process of these secondary metabolites in plants. The presence of glucose units in genistin (II) and daidzin (IV) is supposed to facilitate hydrosolubility and transport by water during the elimination 9 .

The results obtained in this experiment also point out that the differences observed in all parameters studied for genetically different cultivars are in agreement with results described by other workers with genetically different culti vars of Trifolium subterraneum 11,20 and ononis Spinosa L. 19. Further analysis of Table $V$ also permits the identifica: tion of the cultivar with the highest concentration of flavonoid compounds. This may facilitate future studies.

Table VI points out the high antioxidizing power of

flavonoid compounds. As can be seen, genistein (I) and genistin (II) exhibited the best acidity, iodine and peroxide indexes, when compared to normal values-CNNPA (ABIA) ${ }^{21}$. These values point an acidity index of $\pm 0,423$ percent oleic acid; iodine index of 188-198 in mg/100 and a peroxide index of $20 \mathrm{meq} / \mathrm{kg}$. It is interesting to note that results similar to those obtained by us with soybean oil have also been observed by other 
TABLE I. SOME PHYSICAL PROPERTIES OF THE FLAVONOID COMPOUNDS STUDIEN.

\begin{tabular}{|c|c|c|c|c|}
\hline COMMON NAME & OFFICIAL NAME & $\begin{array}{l}\text { Molecula: } \\
\text { Weight }\end{array}$ & $\begin{array}{l}\text { Literature } \\
\text { m.p. } 9 \mathrm{C}\end{array}$ & $\begin{array}{l}\text { Melting Point } \\
\text { Found oC }\end{array}$ \\
\hline Genistein & $\begin{array}{l}4^{\prime}, 5,7 \text {-trihydroxy- } \\
\text { isoflavone }\end{array}$ & 270,25 & 302 & $300-302$ \\
\hline Genistin & $\begin{array}{l}4^{\prime}, 5 \text {-dinydroxy-7-0- } \\
\text { glucosil isoflavone }\end{array}$ & - & 253 & $251-253$ \\
\hline Daidzein & $\begin{array}{l}4^{\prime}, 7 \text {-dihydroxy- } \\
\text { isoflavone }\end{array}$ & 254,25 & 323 & $321 ; 323$ \\
\hline Daidzin & $\begin{array}{l}4^{\prime} \text {-hydroxy-7-0- } \\
\text { glucosil isoflavone }\end{array}$ & - & 238 & $236-238$ \\
\hline Naringenin & $\begin{array}{l}4^{\prime}, 5,7-t \text { trihydroxy- } \\
\text { flavonone }\end{array}$ & 272,25 & 251 & $249-251$ \\
\hline Kaempherol & $\begin{array}{l}3,4^{\prime}, 5,7 \text {-tetrahydroxy- } \\
\text { flavone }\end{array}$ & 286,23 & 277 & $274-276$ \\
\hline Formonometin & $\begin{array}{l}\text { 7-hydroxy-4 -methoxy- } \\
\text { isoflavone }\end{array}$ & 268,26 & 212 & $210-212$ \\
\hline Biochanin A & $\begin{array}{l}5,7-\text { dihydroxy-4' -methoxy- } \\
\text { isoflavone. }\end{array}$ & $-284,3$ & 284 & $281-283$ \\
\hline
\end{tabular}


SBJ CHEM. Vol 1, No. L, 1993

Flavonoids of Soybean

TABLE II. ULTRAVIOLET SPECTRA OF FLAVONOID COMPOUNDS (WAVELENGTH 'IN NANOMETERS).

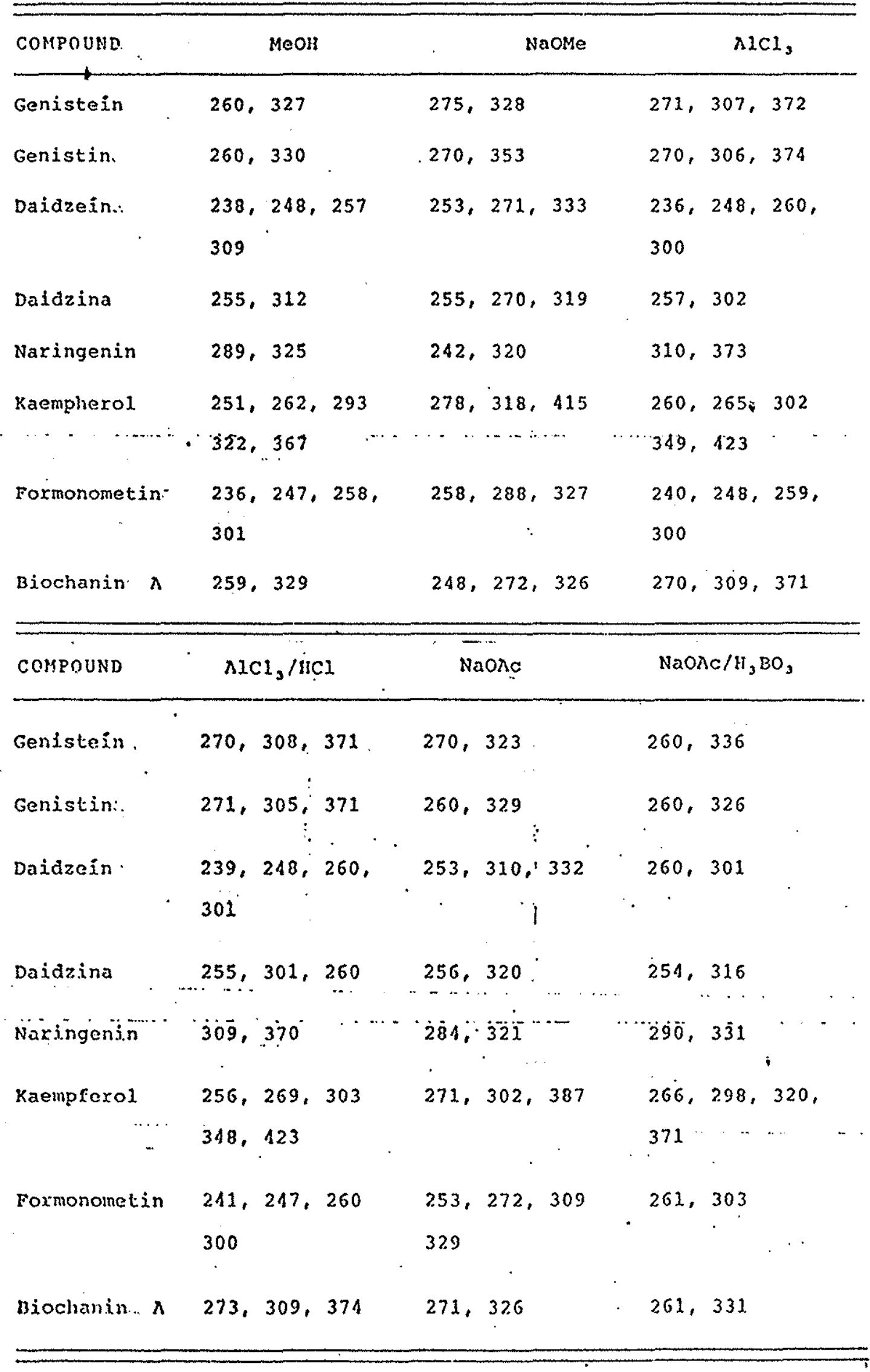


TABLE III. INFRARED SPECTRA OF FLAVONOID COMPOUNDS.

\begin{tabular}{|c|c|}
\hline COMPOUND & WAVELENGTH $\left(\mathrm{cm}^{-1}\right)$ \\
\hline Genisteịn: & $3650-3000,1650,1620,1570,1520,2500,1420,1360,1320,1280,1260,1210,1180,1150,1050$ \\
\hline Genistin: & $3600-3000,1640,1620,1500,1360,2280,1260,1210,1200,1180,1150,1100,1050$ \\
\hline Daidzein " & $3550-3000,1640,1620,1600,1530,1470,1390,1310,1280,1240,1200,1200,1050,890,850$ \\
\hline Daidzin: & $3500-3000,1640,1600,2530,1480,1390,1300,1280,1240,1220,1200,1150,1130,1050$ \\
\hline Naringenin & $3500-3000,1640,1600,1520,1500,1460,1380,1330,1320,1250,1180,1150,1080,1060,890,830$ \\
\hline ' Kaempherol & $3500-3000,1640,1600,1520,1500,1460,1300,1250,1250,1100,1050$ \\
\hline Formonometin & $3500-3000,1640,1600,1570,1515,1460,1390,1320,2290,1270,1250,1200,1180,1100,1040,880$ \\
\hline Biochanin $\mathrm{A}$ & $3400-3000,1650,1620,1570,1520,1440,1360,2290,1250,2190,1250,1050,1030,830$ \\
\hline
\end{tabular}


TABLE IV. PROTON NUCLEAR MAGNETIC RESONANCE SPECTRA OF FLAVONOID COMPOUNDS (CHEMICAL SHIFTS IN PPM).

\begin{tabular}{|c|c|c|c|c|c|c|c|c|c|c|c|c|c|c|}
\hline COMPOUND & & OLVENT & $\mathrm{H}-2$ & $\begin{array}{c}\mathrm{H}-3 \\
\vdots \\
\vdots\end{array}$ & $\mathrm{H}-5$ & $H-6$ & $H-7$ & $\mathrm{H}-\mathrm{8}^{\prime}$ & $\mathrm{H}-2^{\prime}$ & $\mathrm{H}-3^{\prime}$ & $\mathrm{H}-5^{\prime}$ & $H-6$ & $\begin{array}{l}\mathrm{CH}^{\prime} \\
\mathrm{OCH}_{3}\end{array}$ & $\begin{array}{c}\text { Gluco- } \\
\text { sil }\end{array}$ \\
\hline Genisteín. & $\delta$ & $\mathrm{CCI}_{4}$ & 7,60 & $\bar{i}$ & - & 5,8 & - & 6,85 & 7,50 & 6,85 & 6,85 & 7,50 & - & \\
\hline Genistin & $\partial$ & $\mathrm{CCl}_{4}$ & 7,80 & 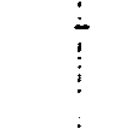 & - & 6,3 & - & 7,10 & 7,50 & 6,85 & 6,85 & 7,50 & - & $\begin{array}{c}H 1-G 1 \underline{v} \\
\operatorname{cosi1} 5,0 / \\
3,90-3,3 \text { (6t) }\end{array}$ \\
\hline Daidzein & $\delta$ & $\mathrm{CCl}_{4}$ & $7,70^{\circ}$ & $\div$ & 8,0 & 6,50 & - & 6,75 & 7,50 & 6,85 & - & 6,85 & 7,50 & \\
\hline Daiazini & $\delta$ & $\mathrm{CCl}_{4}$ & 7,90 & $\div$ & 8,2 & 7,1 & - & 7,0 & 7,50 & 6,85 & - & 6,85 & $\begin{array}{r}7,50 \\
5 \\
3\end{array}$ & $\begin{array}{l}\mathrm{H}-\mathrm{Glucosil} \\
5,0 / 3,85- \\
3,20 \quad(65)\end{array}$ \\
\hline Naringenin & $\delta$ & $\mathrm{CCl}_{4}$ & 5,20 & $\begin{array}{l}2,50-^{\prime} \\
2,90\end{array}$ & - & 5,85 & - & 6,0 & 7,25 & $6,75^{\circ}$ & 6,75 & 7,25 & - & \\
\hline Kaempherol & $\delta$ & $\mathrm{CCl}_{4}$ & - & $\therefore$ & - & 6,15 & - & 6,45 & 8.0 & 6,85 & - & 6,85 & 8,0 & \\
\hline Formonometin. & $\delta$ & $\mathrm{CCl}_{4}$ & 7,70 & $-;$ & 8,0 & 6,50 & - & 6,75 & 7,35 & $6,65:$ & 6,85 & 7,35 & 3,90 & \\
\hline Biochanin A & 8 & $\mathrm{CCl}_{4}$ & 7,65 & $-i$ & - & 6,15 & - & 6,40 & 7,35 & $6,85:$ & 6,85 & 7,35 & 3,8 & \\
\hline
\end{tabular}


nо<smiles>Cc1cc(O)c2c(=O)c(-c3ccc(O)cc3)coc2c1</smiles>

I) Genistein<smiles>CCOc1cc(O)c2c(=O)c(-c3ccc(O)cc3)coc2c1</smiles>

[II] Genistin

110<smiles>O=c1c(-c2ccc(O)cc2)coc2cc(O)ccc12</smiles>

[III] Daidzein

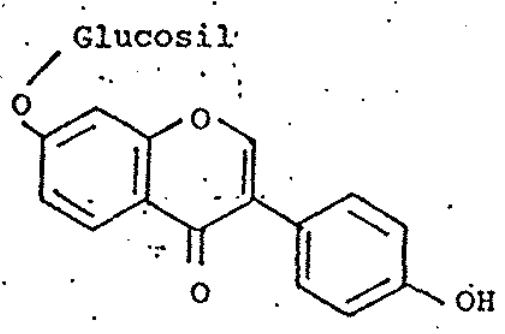

[IV] Daidzin<smiles>O=C1CC(c2ccc(O)cc2)Oc2cc(-c3ccccc3)cc(O)c21</smiles>

(v) Naxingenin :<smiles>COc1ccc(-c2coc3cc(O)ccc3c2=O)cc1</smiles>

[VXI.] Formonometin;<smiles>O=c1c(O)c(-c2ccc(O)cc2)oc2cc(O)cc(O)c12</smiles>

[VI] Kaempferol<smiles>COc1ccc(-c2coc3cc(O)cc(O)c3c2=O)cc1</smiles>

[VIII] Biochanin $A$

FJGURE 1. CHEMICAL STRUCTURES OF THE FLAVONOID COMPOUNDS STUDIED. 
TABLE V. AVERAGE VALUES OBTAINED FOP THE CONTENTS OF FLAVONOID COMPOUNDS IN NINE CULTIVARS OF SOYBEAN.

\begin{tabular}{|c|c|c|c|c|c|c|c|c|}
\hline $\begin{array}{c}\text { Cultivars } \\
\text { of Soya }\end{array}$ & $\begin{array}{l}\text { Protein } \\
(\%)\end{array}$ & $\begin{array}{l}\text { i1 } \\
(\%)\end{array}$ & $\begin{array}{l}\text { : } \\
\text { Genisteini. } \\
(\mathrm{mg} / \mathrm{lo0g})\end{array}$ & $\begin{array}{l}\text { Genistin.: } \\
\text { (mg/100g) }\end{array}$ & $\begin{array}{l}\text { Daidzein. } \\
\text { (mg/loog) }\end{array}$ & $\begin{array}{l}\text { Daidzin } \\
\text { (mg/100g) }\end{array}$ & $\begin{array}{l}\text { Forrionometin } \\
\because(\mathrm{mg} / 100 \mathrm{~g})\end{array}$ & $\begin{array}{l}\text { Biochanina } \\
\therefore(\mathrm{mg} / 100 \mathrm{~g})\end{array}$ \\
\hline Doko & $34.76 \mathrm{G}$ & $20,93 \mathrm{CD}$ & $28,16 \mathrm{~F}$ & $112,00 \mathrm{D}$ & $34,16 \mathrm{~F}$ & $38,16 \mathrm{~F}$ & $34,26 G: 1$ & $66,26 \mathrm{G}$ \\
\hline$I A C-8$ & $37,86 \mathrm{~F}$ & $23,76 \mathrm{~A}$ & $32,16 \mathrm{E}$ & $114,00 \mathrm{CD}$ & $39,16 \mathrm{~B}$ & $50,26 \mathrm{E}$ & $35,23 \quad F$ & $68,26 \mathrm{~F}$ \\
\hline FT॰Cristalina & $38,10 \mathrm{EE}$ & $23,10 \mathrm{AB}$ & $32,00 \mathrm{E}$ & $113,33 \mathrm{CD}$ & $39,00 \mathrm{D}$ & $50,20 \mathrm{E}$ & $35,20 \mathrm{~F}:$ & $68,06 \mathrm{~F}$ \\
\hline $\operatorname{Urv}-1$ & $40,13 \mathrm{D}$ & $20,36 \mathrm{D}$ & $33,: 16 \mathrm{D}$ & $116,66 \mathrm{C}$ & $41,50 \mathrm{C}$ & $52,23 \mathrm{D}$ & $39,40 \mathrm{D}$ & $71,33 \mathrm{CD}$ \\
\hline UEV -5 & $45,20 \mathrm{~A}$ & $23,80 \mathrm{~A}$ & $38,23 \mathrm{~A}$ & $123,00 \mathrm{AB}$ & $48,16 \mathrm{~A}$ & $60,13 \mathrm{~A}$ & $43,23 \mathrm{~A}$ & $77,86 \mathrm{~A}$ \\
\hline UPV-7' & $39,36 \mathrm{DE}$ & $21,40 \mathrm{C}$ & $33,23 \mathrm{D}$ & $120,33 \mathrm{~B}$ & $36,50 \mathrm{~F}$ & $52,16 \mathrm{D}$ & $38,00 \mathrm{E}$ & $70,40 \mathrm{E}$ \\
\hline$U F V-9^{\circ}$ & $42,20 \mathrm{~B}$ & $21,40 \mathrm{C}$ & $36,00 \mathrm{~B}$ & $124,00 \mathrm{~A}$ & $45,23 \mathrm{~B}$ & $57,30 \mathrm{~B}$ & $41,16 \mathrm{~B}$ & $75,30 \mathrm{~B}$ \\
\hline$U F V-10^{\prime}$ & $40,50 \mathrm{CD}$ & $22,40 \mathrm{~B}$ & $33,23 \mathrm{D}$ & $122,00 \cdot A B$ & $41,13 \mathrm{C}$ & $52,40 \mathrm{D}$ & $39,26 \mathrm{D}$ & $71,16 \mathrm{DE}$ \\
\hline UEV $-15^{\prime}$ & $41,66 \mathrm{BC}$ & $22,40 \mathrm{~B}$ & $34,33 \mathrm{C}$ & $124,00 \mathrm{~A}$ & $44,33 \mathrm{~B}$ & $55,16 \mathrm{C}$ & $40,23 \mathrm{C}$ & $72,20 \mathrm{c}$ \\
\hline
\end{tabular}

* The values followed by at least one equal letter do not differ statistically by Tuckey's Test ( $5 \%$ probability level). 
TABLE VI, ANTIOXIDANT ACTION OF FLAVONOID COMPOUNDS. AVERAGE EXPERIMENTAL VALUES OF ACIDITY, IODINE AND PEROXIDE INDEXES .

\begin{tabular}{lccc}
\hline $\begin{array}{l}\text { Mixture of } \\
\begin{array}{c}\text { Soybean Oil } \\
\text { with }\end{array}\end{array}$ & $\begin{array}{c}\text { Acidity Index } \\
\% \text { Oleic Acid }\end{array}$ & $\begin{array}{c}\text { Iodine Index } \\
(\mathrm{mg} / 100 \mathrm{~g})\end{array}$ & $\begin{array}{c}\text { Peroxide Index } \\
(\mathrm{mEq} / \mathrm{kg})\end{array}$ \\
\hline $\begin{array}{l}\text { Genistein. } \\
\text { Genistin. }\end{array}$ & $0,42 \mathrm{CD}$ & $187,66 \mathrm{E}$ & $20,33 \mathrm{D}$ \\
Daidzeir. & $0,41 \mathrm{CD}$ & $187,66 \mathrm{E}$ & $20,33 \mathrm{D}$ \\
Daidzin. & $0,40 \mathrm{CD}$ & $186,00 \mathrm{~F}$ & $18,33 \mathrm{E}$ \\
Naringenin & $0,40 \mathrm{CD}$ & $186,00 \mathrm{~F}$ & $1.8,33 \mathrm{~F}$ \\
Kaemphexol & $0,43 \mathrm{C}$ & $192,33 \mathrm{D}$ & $23,00 \mathrm{BC}$ \\
Formonometin: & $0,40 \mathrm{CD}$ & $186,00 \mathrm{~F}$ & $18,33 \mathrm{E}$ \\
Biochanin A & $0,45 \mathrm{C}$ & $193,00 \mathrm{~A}$ & $24,00 \mathrm{~B}$ \\
\hline Soybean Oil without & $0,38 \mathrm{D}$ & $190,66 \mathrm{C}$ & $22,00 \mathrm{C}$ \\
Antioxidant & $3,55 \mathrm{~A}$ & $54,00 \mathrm{G}$ & $36,33 \mathrm{~A}$ \\
\hline Refined Soybean 0il & $0,54 \mathrm{~B}$ & $188,33 \mathrm{D}$ & $20,00 \mathrm{D}$ \\
\hline Nith Antioxidant & & & \\
\hline
\end{tabular}

* The values followed by at least one equal letter do not ciffer statistically by Tuckey's Test ( $5 \%$ probability level).

workers studying other flavonoids in various plants $1-3,22$.

In conclusion we can firmly state that the analysis of nuclear magnetic resonance, ultraviolet and infrared spectra led to the identification of flavonoid compounds in nine cultivars of soya. The quantification results permit us to conclude that the leguminosa (soybean) is rich in flavonoid compounds and also $\mathrm{rich}$ in proteins, the highest values being obtained for Cultivar UFV-5'.

The efficiency of flavonoid compounds as antioxidants was verified by acidity, iodine and peroxide indexes. The best results were obtained for genistein (I) and genistin (II). 


\section{REFERRNCES}

1. R. A. Larson, Phytochem., 27,969-978 (1988).

2. G. A. Richardson and M. L. El-Rafey, J. Dairy Sci., 30, 397-413 (1974).

3. J. A. Araüjo and D. E. Pratt, Cienc. Tecnol. Aliment.,5, $22-30(1985)$.

4. D. A. Smith and V. B. Stephen, Phytochem., 25, 979-995 (1986).

5. G. B. Russe1, G. J. Shaw, R. E. Christmas, M. B. Yates, R.W. Oliver and 0.R. W. Sutherland, Phytochem., 23, 1417-1420 (1984).

6. P. J. Kuhn, D. A. Smith and D. F. Ewing, Phytochem., 26, 296-297 (1977).

7. S. K. Waage and P. A. Hedin, Phytochem., 23, 2509-2511 (1984).

8. P. A. Hedin, J. N. Jenkins, D. H. Collum, W. H. White and W. L. Parrot, in "Plant Resistance to Insects", ACS Symposium Series $N O$ 257, P. A. Hedin, Editor, American Chemical Society, Washington, D.C., USA, 1984, p. 171 .

9. R. M. Horwitz, in "Biochemistry of Phenolic Compounds", J. B. Harborne, Editor, Academic Press, London, 1964 , pp. 545-572.

10. R. B. Bradbury and D. E. White, Vitamins and Hormones, 22 , 207-233 (1954).

11. J. J. Patroni, V. J. Collins and W. R. Stern, J. Chromat., $247,366-368(1982)$.

12. M. Naim, B. Gestetner, I. Kirson and A. Bondi, Phytochem., 22, 169-170 (1973).

13. J. B. Murphy and C. A. Stutte, Analyt. Biochem.,86, 220228 (1978).

14. H. Pregnolatto and N. P. Pregnolatto, in "Normas Analiticas do Instituto Adolfo Lutz", São Paulo, 1985, Vol. I, pp. 245-261.

15. M. N. Bradford, Analyt. Biochem., 72, 248-254 (1976).

16. A. C. Eldridge, J. Chromat., 234, 494-497 (1982).

17. K.S. Mathur, S.S. Singhal and R. D. Sharma, J. Nutrit., 84 , 164 (1964).

18. E. Farmalidis and P. A. Murphy, J. Chromat., 295, 513-515 (1984).

19. G. F. Nicollier and A. C. Thompson, J. Chromat., 249, 399-402 (1982).

20. P. Piergiorgio and C. Zio, J. Chromat., 260, 497-501 (1983). 
SBJ CHRM., Vol. 1, No. 1, 1993

$$
\text { T.J. Nagem et al. }
$$

21. CNNPA - Associação Brasileira das Indústrias de Alimentação, São Paulo, 1969, VI, pp. 245-246.

22. D. E. Pratt and P. M. Birac, J. Food Sci., 44, 1720-1749 (1979).

23. J. L. Firmin, K. E. Wilson, L. Rossen and A. W. B. Johnston, Nature, 324, 90 (1986).

24. N. K. Peters, J. W. Frost and S. R. Long, Science, 233, 977 (1986).

25. J. W. Redmond, M. Batley, M. A. Djordjevic, R. W. Imnes, P. L. Kuempel and B. G. Rolfe, Nature, 323, 632 (1986).

26. H. P. Spaink, C. A. Wijffelman, E. Pees, R. J. H. Okker and B. J. J. Lugtemberg, Nature, 328, 337 (1987).

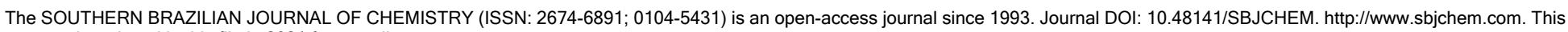
text was introduced in this file in 2021 for compliance reasons.

(C) The Author(s)

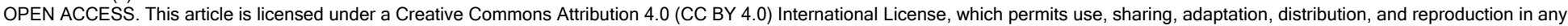

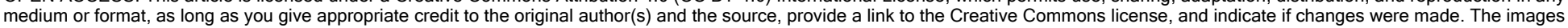

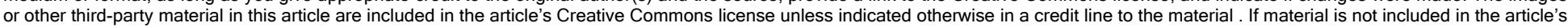

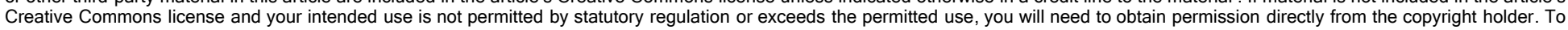
view a copy of this license, visit http://creativecommons.org/licenses/by/4.0/. 